\title{
Knowledge and Use of Dietary Supplement Products by Deaf Athletes
}

\author{
Pelin Aksen Cengizhan \\ Correspondence: Pelin Aksen Cengizhan, Faculty of Sport Science, Kırıkkale University, Kırıkkale, Turkey.
}

Received: March 25, 2018

doi:10.11114/jets.v6i6.3231
Online Published: April 23, 2018

Accepted: April 20, 2018

URL: https://doi.org/10.11114/jets.v6i6.3231

\begin{abstract}
The purpose of this study was to determine the knowledge and use of dietary supplement products (DSP) among the deaf athletes of the Turkish Deaf Sports Federation. A total 74 voluntary athletes from various sports, 11 female and 63 male athletes $\left(\mathrm{M}_{\mathrm{age}}=23.62 \pm 5.38\right.$ years $)$ participated in this study. The data was collected through the survey method and was analyzed by Fischer Exact test, frequencies and percentage distribution. As a result, it has been determined that $39.2 \%$ of deaf athletes have knowledge about DSP and athlete diets; their rate of DSP use increases as their educational level increases; the rate of DSP use in national athletes is higher and that taekwondo athletes do not use DSP while a rate of at least 30.8\% DSP use is evident in other branches. In addition, the findings show that the deaf athletes do not have sufficient knowledge about their DSP use and they have problems in accessing reliable information about this issue.
\end{abstract}

Keywords: athletes, deaf, dietary support products, nutrition, people with disabilities

\section{Introduction}

Genetic structure, suitable exercise and balanced diets are the primary factors which affect the performance of athletes. As athletes' performance can be enhanced through a balanced diet, it can ve negatively affected through an unbalanced diet (Fox, Bowers, \& Foss, 1999). Athletes spend great effort for a higher performance and spend a majority of their time and energy on exercise, however they cannot get full benefit from their efforts due to diets which are not suitable for them, cause an adverse effect or sometimes harm them (Ersoy, 2014; Katch, Katch, \& Mcardle, 1994). Cupisti et al. (2002) have found out that a proper and balanced diet is important for the athletes in many ways. Many conditions which affect athletes directly or indirectly such as increasing the performance, preventing weight loss and excessive weight gain, preventing illnesses caused by the electrolyte loss in the body, proper functioning of the digestive system and renewal of sources of energy in the recovery period, can be made possible through a proper diet.

Diets are regarded as one of the most important factors which the athletes can control when they have knowledge about them and affect their performance (Turgut et al., 2015). Therefore, athletes need to have sufficient knowledge about diets in order to be able to improve their performance and obtain successful results (Süel et al., 2009). Athletes who regularly exercise and participate in competitions need more knowledge about diets and correct diet programs compared to people who exercise for leisure and health (Özdemir \& Ersoy, 2009). However, it is considered that many people who participate in sports do not have sufficient information about balanced diets and that erroneous applications are common among athletes and can create dangerous results (Süel et al., 2006).

Dietary supplement products (DSP) are defined as all kinds of exercise techniques, mechanical devices, nutritional supplements, pharmacological supplements or physiological technical ergogenic support, which aim at increasing exercise performance or exercise adaptation (Kreider et al., 2010). These aids can be effective in preparing athletes for exercise, increasing the productivity of exercise or recovery after exercise. Dietary supplement products are an issue which should be carefully considered since they affect the general health and sportive performance of athletes. Athletes are recommended to use dietary supplement products in favorable conditions. In cases where these products are necessary, the use of the accurate product at the right time and in the accurate amount provides benefits in terms of increasing performance. (Yarar et al., 2011).

Diet has an important place in the life of all athletes as one of the aspects which affect physical performance (Mcardle, Katch, \& Katch, 2010; Özdemir \& Ersoy, 2009). In DSP use in deaf and people with disabilities, besides a series of general principles which should be taken into consideration such as individual differences and physiological demands unique to the sport which are advised to be given importance to in terms of all athletes in general, there are also other cases which require different suggestions (Crosland \& Broad, 2011). However, in general the number of studies on the 
use of DSP by people with disabilities is quite limited (Özdemir \& Ersoy, 2009; Crossland \& Broad, 2011) and research on deaf individuals has not come to the fore among these limited studies. Crosland and Broad (2011) have stated the difficulties experienced in reaching out to sufficient number of individuals/athletes for scientific studies on this subject.

For instance, it is suggested for sports dieticians to advise athletes with disabilities who actively engage in sports in terms of sufficient and balanced diets, the effect of diets on performance, the importance of fluid consumption and ergogenic support (Özdemir \& Ersoy, 2009). In addition, the critical evaluation of the validity of what is suggested about the importance of a proper diet and special diets with dietary supplement products requires expertise and the appropriate points of views (McArdle et al., 2010). Despite the importance of diets, it is known that there is lack of information on this subject (Özdemir, 2009).

It is noteworthy that there is a limited number of studies on diets and DPS applications which have significant effects on performance in an environment in which the number of competitions and activities where disabled and deaf individuals can compete and disabled sports are becoming more competitive (Crosland \& Broad 2011), as well as general health Crosland and Broad 2011, Özdemir \& Ersoy, 2009). There are no studies in related literature in which the knowledge level of deaf athletes regarding DPS has been analyzed.

The primary goal in the evaluation of diets of disabled athletes is to define the consumption of the individual, know the mistakes he is doing and design the most suitable diet plan by suggesting the required changes. In the light of the information to be obtained, negative consequences arising from the insensible use of dietary supplement products can be prevented.

The purpose of the study is to determine the use of dietary supplement products by hearing handicapped athletes and their knowledge on the issue and to analyze whether there is a relationship between their educational level, sports branch, being a national team athlete, monthly average income level, money allocated for their diets and the use of dietary supplement products.

\section{Method}

\subsection{Participant (Subject) Characteristics}

Deaf athletes $(\mathrm{N}=73)$ with the age average of $23.62 \pm 5.38$ years, height average of $180.30 \pm 8.28 \mathrm{~cm}$ and body weight average of $74.70 \pm 12.76 \mathrm{~kg}$ have participated voluntarily in the study in the Turkish national team camp (Table 1), 11 of whom were female and 63 of whom were male from 6 different branches, being basketball, volleyball, handball, taekwondo, swimming and track and field. The athletes were given a survey with the purpose of determining their use of dietary supplement products and their knowledge levels about these products. The regulations state that at least $55 \mathrm{~dB}$ hearing loss in better ear according to the rules of the International Committee of Sports for the Deaf (ICSD) and Deaflympics-Games and in audiological terms, have participated in the study. Prior to the study, approval has been received from Kırıkale University, Clinical Researches Ethics Committee (Decision No: 11/10, Date: 19/04/2016).

Table 1. Descriptive statistics related to the personal characteristics of the athletes

\begin{tabular}{llllll}
\hline & Mean & Median & SD & Minimum & Maximum \\
\hline Age & 23.62 & 23.00 & 5.38 & 14 & 38 \\
Height & 180.30 & 180.00 & 8.28 & 160 & 198 \\
Weight & 74.70 & 73.50 & 12.76 & 49 & 107 \\
Sport experience (year) & 11.38 & 12.00 & 6.11 & 2 & 32 \\
Duration of weekly participation in the sport (days) & 4.40 & 4.75 & 1.40 & 1 & 7 \\
Duration of daily participation in the sport (hours) & 2.17 & 2.00 & 0.73 & 1 & 5 \\
\hline
\end{tabular}

\subsection{Data Collection Tool}

The participants were given the survey form consisting of multiple choice questions and open ended questions. The survey consisted of 38 questions in 3 parts, on general knowledge, information about dietary supplement products, and athletes' knowledge on their use and athlete diets.

The survey was prepared by experts on the subject (Ünsal, Özdemir, \& Ersoy, 2010; Yarar, et al., 2011) and used in this study with their permission.

Prior to the survey, the translator who knows Turkish Sign Language (TSL) carried out pre-studies together with volunteering deaf participants whose primary language is TSL and have active communication with the deaf community in Turkey with the purpose of calculating the possible equivalent of each statement in the survey from in TSL and to present a more accurate translation. 
The surveys were distributed to deaf athletes who volunteered to participate in the study after the purpose of the study was indicated. The participants preferred access in TSL, since they frequently use sign language and translators. The surveys were translated by the TSL translator and given using sign language through the face to face survey method.

\subsection{Statistical Analysis}

The statistical analysis related to the study was carried out by the SPSS 19 package program and the significance value has been determined as 0.05 . The average, median and standard variation values and frequency-percentage distributions of the personal characteristics of the athletes were turned tabulated with the use of descriptive statistics. For the only sample which tests whether an individual or objects displays a significant difference according to the levels of a categorical variable, the Chi-Square test was used. Actually, the test analyzes the significance of the difference between the numbers observed in each category of the variable and the numbers expected for the categories (Büyüköztürk, 2014). The answers given to the questions in the survey with the purpose of determining the dietary supplement products and their usage status were tabulated for frequency and percentage values according to various variables. The intergroup percentile distribution relationship of the given answers were determined with the Fischer Exact test and indicated in tables.

\section{Results}

Table 2. Sociodemographic Characteristics of The Deaf Athletes

\begin{tabular}{|c|c|c|c|}
\hline Variable & Level & Frequency & $\%$ \\
\hline \multirow[t]{2}{*}{ Gender } & Female & 11 & 14.9 \\
\hline & Male & 63 & 85.1 \\
\hline \multirow[t]{3}{*}{ Educational Status } & Primary & 20 & 27.0 \\
\hline & High-school & 46 & 62.2 \\
\hline & University & 8 & 10.8 \\
\hline \multirow[t]{4}{*}{ Occupation } & Laborer & 16 & 21.6 \\
\hline & Civil Servant & 9 & 12.2 \\
\hline & Self-employment & 6 & 8.1 \\
\hline & Student and other & 43 & 58.1 \\
\hline \multirow[t]{2}{*}{ National Sportsmanship History } & Yes & 59 & 79.7 \\
\hline & First Participation & 15 & 20.3 \\
\hline \multirow[t]{2}{*}{ Where the athlete lives } & With family & 65 & 87.8 \\
\hline & other & 9 & 12.2 \\
\hline \multirow[t]{2}{*}{ The average income of the household } & Below $2000 \mathrm{TL}$ & 43 & 58.1 \\
\hline & $2000 \mathrm{TL}$ and higher & 31 & 41.9 \\
\hline \multirow[t]{2}{*}{ Monthly average amount of money allocated for food } & Below $200 \mathrm{TL}$ & 30 & 40.5 \\
\hline & $200 \mathrm{TL}$ and higher & 44 & 59.5 \\
\hline \multirow[t]{5}{*}{ Branch } & Volleyball & 13 & 17.6 \\
\hline & Basketball & 21 & 28.4 \\
\hline & Handball & 16 & 21.6 \\
\hline & Taekwondo & 18 & 24.3 \\
\hline & Swimming & 6 & 8.1 \\
\hline
\end{tabular}

In the study carried out with the purpose of determining the use of dietary supplement products by hearing impaired athletes whose age average was $23.62 \pm 5.38$ years and their knowledge levels about these products, it has been seen that $27 \%$ of the participants were primary, $62.2 \%$ were high school and $10.8 \%$ were university graduate athletes. In addition, it has been determined that $79.7 \%$ were national team athletes and $20.3 \%$ had attended the national team camp for the first time. When they were evaluated according to the distribution in sports branches, it was seen that the most participation was in the basketball branch $(21.6 \%)$. It was determined that $58.1 \%$ of the participants were students; most of them lived with their families )87.8\%); in 58.1\% the monthly wage of the families were below 2000 TL and $59.5 \%$ could allocate less than an average of 200TL monthly for their diets (Table 2). 
Table 3. Characteristics and frequency distribution related to the dietary supplement product

\begin{tabular}{llll}
\hline Variable & Level & Frequency & $\%$ \\
\hline Do you use a dietary supplement product? & Yes & 23 & 31.1 \\
\cline { 2 - 4 } & No & 51 & 68.9 \\
\hline Where do you buy the dietary supplement product? & Shop & 18 & 90.0 \\
\cline { 2 - 4 } & Pharmacy & 2 & 10.0 \\
\hline Have got knowledge about dietary supplements? & Yes & 20 & 39.2 \\
\cline { 2 - 4 } & No & 18 & 35.3 \\
\cline { 2 - 4 } & Not sufficient & 13 & 60.0 \\
\hline If yes, from where have you acquired information? & From my coach & 30.0 \\
\cline { 2 - 4 } & Lessons & 2 & 10.0 \\
\cline { 2 - 4 } & Books, newspapers and magazines & 2 & 13.0 \\
\hline The purpose of using the dietary supplement product & Vitality & 3 & 56.5 \\
\cline { 2 - 4 } & Increasing performance & 13 & 30.5 \\
\cline { 2 - 4 } & Increasing muscle mass & 7 & 69.6 \\
\cline { 2 - 4 }
\end{tabular}

When we take a look at Table 3, it is possible to see that $68.9 \%$ of the participants did not use any dietary supplement products and that $90 \%$ of those who used these products bought them from stores. It can be seen that only $39.2 \%$ are knowledgeable about dietary supplement products and athlete diets. $60 \%$ of those who had knowledge about dietary supplement products and athlete diets stated that they received information from their coaches. While $56.5 \%$ of the athletes who used dietary supplement products stated that their purpose was to increase performance, $69.6 \%$ stated that they have seen these products' benefits.

Table 4. Frequency distribution of views on the relationship between diet and success in sports

\begin{tabular}{lll}
\hline Answer & Frequency & $\%$ \\
\hline No relationship & 17 & 23.3 \\
\hline Very closely related & 42 & 57.5 \\
\hline I have no knowledge about it & 14 & 19.2 \\
\hline
\end{tabular}

Table 5. Frequency distribution on views related to the need of diet

\begin{tabular}{lll}
\hline Answer & Frequency & $\%$ \\
\hline No & 65 & 90.3 \\
\hline Yes & 5 & 6.9 \\
\hline Sometimes & 2 & 2.8 \\
\hline
\end{tabular}

$57.5 \%$ of the participants of the study stated that there is a very close relationship between diets in sports and success; $23.3 \%$ stated that there is no relationship between diets and success, $19.2 \%$ stated that they had no knowledge about this issue (Table 4) and $90.3 \%$ stated that they did not feel the need to go on a diet (Table 5).

When we take a look at Table 6 , it can be seen that $65.3 \%$ of the participants stated that they had 3 meals per day; almost half of the participants (45.9\%) stated that they skipped lunch and $35.2 \%$ stated that they skipped meals since they did not have enough time. $41.7 \%$ of the athletes stated that they drank 3-4 liters of fluids per day and $90.3 \%$ stated that they had fluids while doing sports, $80.6 \%$ stated that they had fluids during exercise and exercise breaks and $54.3 \%$ stated that they had fluids after exercise. $49.3 \%$ of the athletes who had a meal before exercise $(54.2 \%)$ stated that it was rich in proteins, while $23.9 \%$ stated that it was rich in protein and carbohydrates. 
Table 6. Distribution of eating-drinking characteristics and frequency

\begin{tabular}{|c|c|c|c|}
\hline Variable & Level & Frequency & $\%$ \\
\hline \multirow{3}{*}{$\begin{array}{l}\text { How many meals do you have in } \\
\text { one day? }\end{array}$} & 2 & 7 & 9.7 \\
\hline & 3 & 47 & 65.3 \\
\hline & 4 & 18 & 25.0 \\
\hline \multirow[t]{4}{*}{ Which meal do you skip? } & Breakfast & 14 & 23.0 \\
\hline & Lunch & 28 & 45.9 \\
\hline & Dinner & 5 & 8.2 \\
\hline & Snacks & 14 & 23.0 \\
\hline \multirow[t]{5}{*}{ Why do you skip a meal? } & Due to not having enough time to eat & 19 & 35.2 \\
\hline & I don't have an appetites & 16 & 29.6 \\
\hline & Due to financial difficulties & 3 & 5.6 \\
\hline & Due to choosing meals & 4 & 7.4 \\
\hline & To control my body weight & 12 & 22.2 \\
\hline \multirow{4}{*}{$\begin{array}{l}\text { How many liters of water do you } \\
\text { drink in one day? }\end{array}$} & $0.5-1$ & 10 & 13.9 \\
\hline & $1-2$ & 27 & 37.5 \\
\hline & $3-4$ & 30 & 41.7 \\
\hline & 5 and more & 5 & 6.9 \\
\hline \multirow{4}{*}{$\begin{array}{l}\text { How many hours prior to exercise } \\
\text { do you eat? }\end{array}$} & $1 / 2$ & 2 & 2.8 \\
\hline & 1 & 3 & 4.2 \\
\hline & 2 & 39 & 54.2 \\
\hline & $3-4$ & 28 & 38.9 \\
\hline \multirow{4}{*}{$\begin{array}{l}\text { Which drink do you have while } \\
\text { exercising? }\end{array}$} & Water & 65 & 90.3 \\
\hline & Fruit juice & 2 & 2.8 \\
\hline & Salty ayran & 1 & 1.4 \\
\hline & Sports drinks & 4 & 5.6 \\
\hline \multirow[t]{4}{*}{ What do you eat prior to exercise? } & Nothing & 13 & 18.3 \\
\hline & Protein rich food & 35 & 49.3 \\
\hline & Carbohydrate rich food & 6 & 8.5 \\
\hline & Protein+Carbohydrate rich food & 17 & 23.9 \\
\hline \multirow{2}{*}{$\begin{array}{l}\text { During exercise, what do you drink } \\
\text { between sets? }\end{array}$} & Water & 58 & 80.6 \\
\hline & Other & 12 & 19.4 \\
\hline \multirow[t]{5}{*}{ What do you eat after exercise? } & I drink water & 38 & 54.3 \\
\hline & Carbohydrate rich food & 9 & 12.9 \\
\hline & Fruit & 8 & 11.4 \\
\hline & I drink fruit juice & 7 & 10.0 \\
\hline & Other & 8 & 11.4 \\
\hline
\end{tabular}

Table 7. Frequency distribution of views on food which increase physical activity

\begin{tabular}{llll}
\hline Answer & Order & Frequency & $\%$ \\
\hline Meat and meat products & 3 & 15 & 31.9 \\
\hline Butter & 2 & 14 & 29.8 \\
\hline Milk and derivatives & 4 & 22 & 46.8 \\
\hline Honey and molasses & 5 & 33 & 70.2 \\
\hline Pasta, bulgur wheat, rice & 1 & 16 & 34.0 \\
\hline
\end{tabular}

As it can be seen in Table 7, a majority of the participants of the study (70.2\%) preferred honey and molasses as the nutrients which affect performance.

When the questions and answers to DSP, their effects and use are analyzed, it can be seen that $81.4 \%$ of the participants stated that it is absolutely necessary to use additional vitamins and minerals and that vitamins gave energy to the body; $57.7 \%$ stated that additional proteins should be used to increase muscle volume and $52.2 \%$ stated that all herbal products are harmless (Table 8 ). 
Table 8. Questions and answers related to the views on dsp, their effects and usage

\begin{tabular}{|c|c|c|c|c|}
\hline Question & & Right & I Don't Know & Wrong \\
\hline \multirow[t]{2}{*}{ Supplementary vitamins must be used } & $\mathrm{f}$ & 57 & 10 & 3 \\
\hline & $\%$ & 81.4 & 14.3 & 4.3 \\
\hline \multirow[t]{2}{*}{ Vitamins provide energy for the body } & $\mathrm{f}$ & 57 & 7 & 6 \\
\hline & $\%$ & 81.4 & 10.0 & 8.6 \\
\hline \multirow[t]{2}{*}{ Antioxidants do not harm the immunity system } & $\mathrm{f}$ & 13 & 48 & 9 \\
\hline & $\%$ & 18.6 & 68.6 & 12.9 \\
\hline \multirow[t]{2}{*}{ All herbal products are safe } & $\mathrm{f}$ & 36 & 23 & 10 \\
\hline & $\%$ & 52.2 & 33.3 & 14.5 \\
\hline \multirow[t]{2}{*}{ Everyone can use multivitamins } & $\mathrm{f}$ & 12 & 33 & 23 \\
\hline & $\%$ & 17.6 & 48.5 & 33.8 \\
\hline \multirow[t]{2}{*}{ There is no need to consult a doctor to use dietary supplement products } & $\mathrm{f}$ & 16 & 16 & 39 \\
\hline & $\%$ & 22.5 & 22.5 & 54.9 \\
\hline \multirow{2}{*}{ Dosage is not important for us while using dietary supplement products } & $\mathrm{f}$ & 7 & 20 & 42 \\
\hline & $\%$ & 10.1 & 29.0 & 60.9 \\
\hline \multirow[t]{2}{*}{ There is no harm in consuming more vitamins and minerals than necessary } & $\mathrm{f}$ & 21 & 15 & 35 \\
\hline & $\%$ & 29.6 & 21.1 & 49.3 \\
\hline \multirow{2}{*}{$\begin{array}{l}\text { In order to increase muscle mass, more protein supplements than necessary } \\
\text { is necessary }\end{array}$} & $\mathrm{f}$ & 41 & 12 & 18 \\
\hline & $\%$ & 57.7 & 16.9 & 25.4 \\
\hline
\end{tabular}

Table 9. Usage of dietary supplement products in accordance with educational level of the participants

\begin{tabular}{|c|c|c|c|c|c|}
\hline \multirow{2}{*}{ Usage of dietary supplement products } & & \multicolumn{4}{|c|}{ Educational status } \\
\hline & & Primary & High-school & University & Total \\
\hline \multirow[t]{2}{*}{ Yes } & $\mathrm{f}$ & 3 & 17 & 3 & 23 \\
\hline & $\%$ & $15.0 \%$ & $37.0 \%$ & $37.5 \%$ & $31.1 \%$ \\
\hline \multirow[t]{2}{*}{ No } & $\mathrm{f}$ & 17 & 29 & 5 & 51 \\
\hline & $\%$ & $85.0 \%$ & $63.0 \%$ & $62.5 \%$ & $68.9 \%$ \\
\hline \multirow[t]{2}{*}{ Total } & $\mathrm{f}$ & 20 & 46 & 8 & 74 \\
\hline & $\%$ & $100.0 \%$ & $100.0 \%$ & $100.0 \%$ & $100.0 \%$ \\
\hline
\end{tabular}

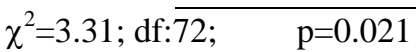

Table 10. Crosstab and fischer exact test to determine the relationship between being a national athlete and the usage of dietary supplement products

\begin{tabular}{|c|c|c|c|c|}
\hline \multirow{2}{*}{ Usage of dietary supplement products } & \multicolumn{3}{|c|}{ National athlete } & \multirow[b]{2}{*}{ Total } \\
\hline & & Yes & No & \\
\hline \multirow{2}{*}{ Yes } & $\mathrm{f}$ & 22 & 1 & 23 \\
\hline & $\%$ & $37.3 \%$ & $6.7 \%$ & $31.1 \%$ \\
\hline \multirow{2}{*}{ No } & $\mathrm{f}$ & 37 & 14 & 51 \\
\hline & $\%$ & $62.7 \%$ & $93.3 \%$ & $68.9 \%$ \\
\hline \multirow{2}{*}{ Total } & $\mathrm{f}$ & 59 & 15 & 74 \\
\hline & $\%$ & $100.0 \%$ & $100.0 \%$ & $100.0 \%$ \\
\hline
\end{tabular}

$\chi^{2}=1.47 ; \mathrm{df}: 72 ; \mathrm{p}=0.032$

Table 11. Crosstab and the chi-square test to determine the relationship between average monthly income and the usage of dietary supplement products

\begin{tabular}{|c|c|c|c|c|}
\hline \multirow{2}{*}{ Usage of dietary supplement products } & & \multicolumn{3}{|c|}{ Average monthly income of the household } \\
\hline & & Below $2000 \mathrm{TL}$ & $2000 \mathrm{TL}$ and higher & Total \\
\hline \multirow{2}{*}{ Yes } & $\mathrm{f}$ & 12 & 11 & 23 \\
\hline & $\%$ & $27.9 \%$ & $35.5 \%$ & $31.1 \%$ \\
\hline \multirow{2}{*}{ No } & $\mathrm{f}$ & 31 & 20 & 51 \\
\hline & $\%$ & $72.1 \%$ & $64.5 \%$ & $68.9 \%$ \\
\hline \multirow{2}{*}{ Total } & $\mathrm{f}$ & 43 & 31 & 74 \\
\hline & $\%$ & $100.0 \%$ & $100.0 \%$ & $100.0 \%$ \\
\hline
\end{tabular}

$\chi^{2}=0.48 ;$ df: $72 ; \mathrm{p}=0.171$ 
Table 12. Crosstab and the chi-square test to determine the relationship between money allocated for food and the usage of dietary supplement products

\begin{tabular}{|c|c|c|c|c|}
\hline \multirow{2}{*}{ Usage of dietary supplement products } & & \multicolumn{3}{|c|}{ Average monthly money allocated for food } \\
\hline & & Below $200 \mathrm{TL}$ & $200 \mathrm{TL}$ and higher & Total \\
\hline \multirow{2}{*}{ Yes } & $\mathrm{f}$ & 8 & 15 & 23 \\
\hline & $\%$ & $26.7 \%$ & $34.1 \%$ & $31.1 \%$ \\
\hline \multirow{2}{*}{ No } & $\mathrm{f}$ & 22 & 29 & 51 \\
\hline & $\%$ & $73.3 \%$ & $65.9 \%$ & $68.9 \%$ \\
\hline \multirow{2}{*}{ Total } & $\mathrm{f}$ & 30 & 44 & 74 \\
\hline & $\%$ & $100.0 \%$ & $100.0 \%$ & $100.0 \%$ \\
\hline
\end{tabular}

$\chi^{2}=0.46 ; \mathrm{df}: 72 ; \mathrm{p}=0.421$

When we take a look at Table 9, it can be stated that there is a relationship between educational status and use of dietary supplement products according to the results of the Chi square test $\left(\chi^{2}=3.31\right)(\mathrm{p}<0.05)$. When the frequencies are analyzed, it is seen that the rate of using dietary supplement products increases as the educational level increases. While the rate using dietary supplement products is $15 \%$ in primary school graduates, it is $37.5 \%$ in university graduates. As it can be seen in Table 10, according to the results of the Fischer Exact test, there is a relationship between having a national athlete background and the usage of dietary supplement products $\left(\chi^{2}=1.47 ; \mathrm{p}<0.05\right)$. When the frequencies are analyzed, it is seen that the rate of using dietary supplement products is higher in national athletes. In addition, according to the results of the Chi square test $\left(\chi^{2}=0.48 ; \mathrm{p}>0.05\right)$, it can be stated that there is no relationship between average monthly income and the usage of dietary supplement products (Table 11) and that similarly according to the results of the same test $\left(\chi^{2}=0.46\right.$; df:72; $\left.=0.421\right)$, there is no relationship between money allocated for food and the usage of dietary supplement products $(\mathrm{p}>0.05)$ (Table 12).

Table 13. Crosstab and fischer exact test to determine the relationship between sports branch and the usage of dietary supplement products

\begin{tabular}{|c|c|c|c|c|c|c|c|c|}
\hline \multirow{2}{*}{$\begin{array}{l}\text { Usage of } \\
\text { products }\end{array}$} & \multirow{2}{*}{ supplement } & & \multicolumn{6}{|l|}{ Branch } \\
\hline & & & Volleyball & Basketball & Handball & Taekwondo & Swimming & Total \\
\hline \multirow{2}{*}{ Yes } & & $\mathrm{f}$ & 4 & 10 & 6 & 0 & 3 & 23 \\
\hline & & $\%$ & $30.8 \%$ & $47.6 \%$ & $37.5 \%$ & $0.0 \%$ & $50.0 \%$ & $31.1 \%$ \\
\hline \multirow{2}{*}{ No } & & $\mathrm{f}$ & 9 & 11 & 10 & 18 & 3 & 51 \\
\hline & & $\%$ & $69.2 \%$ & $52.4 \%$ & $62.5 \%$ & $100.0 \%$ & $50.0 \%$ & $68.9 \%$ \\
\hline \multirow{2}{*}{ Total } & & $\mathrm{f}$ & 13 & 21 & 16 & 18 & 6 & 74 \\
\hline & & $\%$ & $100.0 \%$ & $100.0 \%$ & $100.0 \%$ & $100.0 \%$ & $100.0 \%$ & $100.0 \%$ \\
\hline
\end{tabular}

$\chi^{2}=1.41 ; \mathrm{df}: 72 ; \mathrm{p}=0.015$

As it can be seen from Table 13, according to the results of the Fischer Exact test, it can be stated that there is a relationship between sports branches and the usage of dietary supplement products $\left(\chi^{2}=0.46\right.$; $\left.p<0.05\right)$. When the frequencies are analyzed, it is seen that, in particular taekwondo athletes do not use dietary supplement products, whereas in other branches there is a minimum rate of $30.8 \%$ and a maximum of $50 \%$ usage of supplementary products.

\section{Discussion}

It has been seen that $39.2 \%$ of the participants of the study, which analyzes the use of dietary supplement products by deaf athletes and their knowledge levels about these products, have knowledge about these products (Table 3). It was found in Süel et al's study (2009) on the knowledge and habits of basketball players regarding diets that $35 \%$ of them and in another study by Süel et al. (2006) on elite basketball players, $42 \%$ of them were knowledgeable. In a study carried out by Yarar et al. (2011) on the knowledge and habits of elite athletes, it was found that $56 \%$ of them; in a study carried out by Pulur ve Cicioğlu (2001) on the knowledge and habits of female basketball players, 52\% of them; in a study carried out by Göral, Saygin and Karacabey (2010) on the knowledge and habits of amateur and Professional athletes, 65.8\% of Professional football players and $40.8 \%$ of amateur football players were knowledgeable about DSP. The findings of our study are in parallel with the findings of other studies on individuals who do not have hearing disabilities.

In our study, $60 \%$ of the individuals who have knowledge about dietary supplement products and athlete diets have stated that they have received information from their coaches, 30\% from their classes and 10\% from newspapers and magazines (Table 3). In Süel et al.'s study (2006) on basketball players (61.9\%), the findings are in parallel with the findings of our study. In studies on top level athletes who have no deaf and participate in different individual sports branches (Şenel et al., 2004; Yarar et al., 2011), amateur basketball players (Yıldırım et al., 2005), amateur football players (Göral et al., 2010) and female basketball players (Pulur and Cicioğlu, 2001), it has been determined that the number of athletes who receive information from their coaches about DSP is lower. In a study carried out by Yarar et al. (2011) on the knowledge and habits of elite level athletes with no hearing problems, it was found that while $96.1 \%$ of 
the athletes thought that there is a relationship between sports diets and success, according to the findings of our study, $57.5 \%$ of the deaf athletes stated that they think that there is a very close relationship between sports diets and success. According to Ersoy (1986), most of the coaches are now knowledgeable about athlete diets and DSP. Therefore, it is difficult to say that athletes have accurate information about athlete diets.

When studies on athletes with no hearing problems (Yarar et al., 2011; Göral et al., 2010) are compared with studies on deaf athletes, it has been seen that the use of DSP in deaf athletes was lower (31.1\%) (Table 3). In addition, it can be seen that as the level of education increases, the use of supplementary products increases as well. While the rate of using dietary supplement products in primary school graduates is $15 \%$, this rate has been determined to be $37.5 \%$ in university graduates (Table 9). In Şenel et al.'s (2004) study on the top level athletes in different individual sports branches, the rates of using dietary supplement products according to educational level have been determined as $81.7 \%$ university, $15 \%$ high-school, $1.7 \%$ as primary school, $0.8+$ post-graduate and $0.8 \%$ doctorate graduates.

The purpose of $56.5 \%$ of those who use dietary supplement products $(n=13)$ is to increase performance, $30.5 \%(n=7)$ to increase muscle mass, $13 \%(\mathrm{n}=3)$ vitality. $69.6 \%$ of those who use dietary supplement products $(\mathrm{n}=16)$ stated that they benefitted from the products (Table 3 ).

As it can be seen Table 10, according to the findings of our study, there is a relationship between being a national athlete and using dietary supplement products $(\mathrm{p}<0.05)$. This study displays similarities with the results of Akıl and Gürbüz's (2005) study, in which they analyze the effects of the knowledge level of athletes in the throwing branches (marathon and shot put) of athletics on diets. It has been seen that national athletes have a higher rate of using dietary supplement products.

90\% of individuals who use DSP buy their products from stores. Although Crosland and Broad (2011) find the DSP needs of "deaf, visually impaired or cognitively impaired' athletes similar to other individuals, they state that shopping, accessing food facilities, financial difficulties (feeding difficulties) and social activities are effective on the types of food involved in the daily diet and the amount of energy used and spent daily. According to the findings of our study, it was seen that there is no relationship between the amount of money allocated by deaf athletes for their diets and their use of dietary supplement products ( $>0.05)$ and that there is a relationship between their branches and use of dietary supplement products $(\mathrm{p}<0.05)$.

To the question related to the number of meals they have per day, most of the deaf athletes have replied three meals (65.3\%) (Table 6). In Süel et al.'s (2009) study on basketball players, the participants have stated 3 meals by $65.5 \%, 4$ meals and more by $27.4 \%$. In Yarar et al.'s (2011) study on the knowledge and habits of elite level athletes on diets, participants stated 3 meals by $56.9 \%$, while $37.4 \%$ have stated that they skip snacks. In Pulur and Cicioğlu's (2001) study on female basketball players, participants stated 3 meals by $43 \%, 2$ meals by $32 \%$ and 4 meals by $25 \% .45 .9 \%$ of the participants stated that they ship lunches, $23 \%$ breakfast and snacks and $8.2 \%$ diner. In Turgut et al.'s (2014) study on swimmers, participants stated that they skipped breakfast by $52.04 \%$ and lunch by $41.83 \% .29 .6 \%$ of the participants in the study stated that they skip meals due to not having appetite, $22.2 \%$ due to controlling their body weight, $35.2 \%$ due to not having enough time for meals, $7.4 \%$ due to choosing meals and $5.6 \%$ due to financial difficulties.

Previous studies have shown that the number of meals and their timings affect physical performance. It is considered that athletes who have 5 meals a day display a better performance compared to athletes who have 3 meals a day and that their total exercise productivity increases with 5 meals. It is considered that the athletes' distributing their daily energy intake into 5 meals a day in a balanced manner has a positive effect on their performance. By consuming food in this manner, it has been seen that stability in the athletes' blood sugar levels and saturation in their muscle glycogen stores could be achieved (Eskici, 2015).

Consuming a balanced diet which is sufficient in terms of quality and amount is quite effective prior to, during and after exercise to increase performance to the maximum level. For instance, the most suitable timing is having the last meal 3-4 hours prior to exercise and not exercising on an empty and full stomach (Sağlam, 1993). In this study, the deaf athletes answered the question on how many hours before exercise they eat as 2 hours earlier by $54.2 \%$ and 3-4 hours by $38.9 \%$ ). The findings of Yarar et al.'s (2011) study on the knowledge and habits of elite level athletes on diets and Yildırım et al.'s (2005) study on amateur basketball players are in parallel with the findings of our study. Since athletes' digestion needs to be easy, they need to eat 3 to 4 hours prior to competitions and consume food which is rich in carbohydrates and low in protein and fat (Fink et al., 2017).

Deaf athletes (49.3\%) have stated that prior to exercise, they have a diet which primarily consists of protein, $23.9 \%$ have stated it consists of both protein and carbohydrates and $18.3 \%$ have stated that they do not change their diets prior to exercise or competitions (Table 6).

In Yarar et al.'s study (2011) on the knowledge and habits of elite level athletes on diets, while the athletes stated that 
they did not make any changes in their eating habits prior to exercise and competitions, $26 \%$ stated that they have protein and carbohydrate rich meals and $25.4 \%$ have carbohydrate rich meals.

The deaf athletes stated that they drink water after exercise by $54.3 \%$, have carbohydrate rich meals by $12.9 \%$, eat fruit by $11.4 \%$ and drink fruit juice by $10 \%$. In Yarar et al. (2011) study on the knowledge and habits of elite level athletes on diets, $27.8 \%$ of the athletes stated they do not make any changes in their diets, $27.8 \%$ stated that they have carbohydrate rich meals. However, having carbohydrate rich food prior to exercise and competitions both provides saturation in the glycogen stores and allows the continuity of blood glucose during activity (Maughan, 2002). The deaf athletes stated that they drink water after exercise by $54.3 \%$, have carbohydrate rich meals by $12.9 \%$, eat fruit by $11.4 \%$ and drink fruit juice by $10 \%$. In Yarar et al.'s (2011) study on the knowledge and habits of elite level athletes on diets, $27.8 \%$ of the athletes stated they do not make any changes in their diets, $27.8 \%$ stated that they have carbohydrate rich meals. Since the glycogen re-synthesis speed increases right after competitions or exercise, consuming carbohydrate rich food within the first 2 hours is highly important. Towards the end of competitions, the athlete's performance is negatively affected due to the decrease in the glycogen stores in the liver and blood glucose level (Rodriguez, Dimarco, \& Langley, 2009).

It has been seen that $90.3 \%$ of the deaf athletes mostly meet their fluid intake with water while doing sports (Table 6). The findings of Yarar et al.'s study (2011) and Yıldirım et al.'s study (2005) support the findings of our study. However, in Bozkurt and Nizamlıoglu's (2005) study on students who are actively engaged in sports and go to physical education and sports colleges, they students have preferred sugary fruit juice by $62 \%$ and water by only $14.4 \%$.

For the optimal performance of athletes, dehydration should be prevented. It can be possible to prevent dehydration by encouraging athletes to adopt the habit of drinking fluids in sufficient and appropriate amounts prior to, during and after exercise or competitions. Therefore, performance loss which can arise due to dehydration can be prevented as well. Dehydration causes a decrease in the maximal oxygen consumption, an increase in body temperature and loss of coordination (Fink \& Mikesky, 2017).

Food which contains carbohydrates and electrolytes are beneficial in both preventing the decrease of blood glucose and the emptying of muscle glycogen stores and providing hydration. During competitions, meeting the fluid need with drinks containing carbohydrates helps in the prevention of mental and physical fatigue (Eskici, 2015). There are studies which have shown that athletes who have drinks containing carbohydrates are more successful compared to athletes who only have water (Ostojic \& Mazic, 2002).

While $41.7 \%$ of the deaf athletes in the present study stated that they drink 3-4 liters of water each day, 37.5\% 1-2 liters, 13.9\% 0.5-1 liters and 6.9\% 5 liters and more (Table 6), however when compared with the studies carried out individuals with no hearing impairments, these results display differences (Yarar et al., 2011; Göral et al., 2010). The performance of an individual is affected by dehydration even at a low rate of $1 \%$ of his body weight. Fluid loss which is over 5\% of body weight can lower the productivity of exercise up to 30\%. The National Athletic Trainers Association (NATA) has stated that, athletes need to drink about 2-3 glasses of water or sports drinks 2-3 hours before exercise or competitions, 1-2 glasses of water 10-20 minutes before exercise or competitions and 1-2 glasses of water every 10-15 minutes during competitions (Doane, 2016).

Although most of the athletes in our study have stated that honey and molasses are the nutrients which increase their physical activity (Table 7), it has been seen that different results have been indicated in different studies (Yarar et al., 2011).

When the answers related to questions about DSP, their effects and use are analyzed, it can be seen that $81.4 \%$ of the participants stated that supplementary vitamin and mineral use is absolutely necessary and that vitamins provide energy to the body; $49.3 \%$ stated that an unnecessary amount of vitamins and minerals would be harmful; $48.5 \%$ stated that they have information about the use of multivitamins; 52.2\% stated that all herbal products are harmless and 57.7\% stated that they think that it is necessary to use additional protein supplements in order to increase muscle volume. The athletes need more energy in comparison to sedentary individuals. Depending on the increase of energy need, there is an increase in vitamin and mineral need as well. When athletes have inadequate nutrition, vitamins and minerals can be insufficient; therefore, multivitamin/mineral supplement support can be used. Antioxidant vitamins, especially A, E and $\mathrm{C}$ vitamins are quite efficient on performance (Eskici, 2015); however $68.6 \%$ of the participants have stated that antioxidants have no effect on the immunity system. More than half of the participants have stated that there is no need to consult a doctor to use DSP and that the dosage is not important. On the contrary, DSP should be used after a detailed evaluation in terms of efficiency, reliability, usefulness and legality. In cases where these products are necessary, the use of right products at the right time and in the right amount is helpful in increasing performance. To be able to achieve this, a decision should be made by getting professional help (Ersoy et al., 2016:130).

As a result, it has been determined in this study that although a majority of deaf athletes are national athletes, they do not have information in general about athlete diets and use of dietary supplement products. There is a need to inform 
athletes about the issue and carry out individual evaluations; it may be suggested that difficulties deaf athletes and deaf individuals in general experience in accessing the related sources, for instance linguistic and expert personnel to be solved. Counseling should be provided to deaf athletes who actively participate in sports by sports dieticians in issues such as, sufficient and balanced diets, the effect of diets on performance, the importance of drinking fluids and ergogenic support.

\section{References}

Akil, M., \& Gürbüz, Ü. (2005). The analysis of the level of nutrition knowledge of sportsmen dealth with thrown branches of track and field. Atatürk University Journal of Physical Education and Sports, 7(1), 78-89.

Bozkurt, İ., \& Nizamoğlu, M. (2005). Determination and evaluation of nutritional habits of active sports students in physical education and sport high school. Selçuk University The Journal of Institute of Social Sciences, 14, 209-215.

Büyüköztürk, Ş. (2017). Data analysis for social sciences. Pegem Academy.

Crosland, J., \& Broad, E. (2011). Nutrition for Disability Athletes. In: (Eds): Susan A. Lanham-New, Samantha J. Stear, Susan M. Shirreffs, Adam L. Collins. Sport and Exercise Nutrition. John Wiley \& Sons.

Cupisti, A., D’alessandro, C., Castrogiovanni, S., Barale, A., \& Morelli, E. (2002). Nutrition knowledge and dietary composition in Italian adolescent female athletes and non-athletes. International Journal of Sport Nutrition and Exercise Metabolism, 12(2), 207-219. https://doi.org/10.1123/ijsnem.12.2.207

Doane, J.M. (2016). "Sports Nutrition Topics". National Athletic Trainers' Association (NATA). Hyperlink: [https://www.nata.org/sites/default/files/hydration-guidelines_handout.pdf]. Retrieved on 30 January 2018.

Ersoy, G. (1986). Sports and nutrition. Milli Eğitim Publisher, Ankara, Turkey.

Ersoy, G. (2004). Nutrition for people exercising and doing sports. Nobel Publisher.

Ersoy, G., Rakicioğlu, N., Karabudak, E., Gökmen Özel, H., Köksal, E., Özer, E., ... Aydemir, E. K. (2016). Özel durumlarda beslenme. Pekcan, G. A., Şanlıer, N., \& Baş, M. (Eds.) Türkiye beslenme rehberi 2015 (TÜBER) (pp, 130-131). Kayhan Ajans

Eskici, G. (2015). Nutrition in team sports. International Journal of Human Science, 12(2), 244-265. https://doi.org/10.14687/v12i2.3190

Fink, H. H., \& Mikesky, A. E. (2017). Practical applications in sports nutrition. Jones \& Bartlett Learning.

Fox, E. L., Bowers, R. W., \& Foss, M. L. (1999). Physiological foundations of physical education and sports. Bağırgan Publication.

Göral, K., Saygin, Ö., \& Karacabey, K. (2010). Amateur and professional football player to investigate the level of nutritional knowledge. Journal of Human Sciences, 7(1), 836-856.

Katch, V. L., Katch, F. I., \& Mcardle, W. D. (1994). Student study guide and workbook for essentials of exercise physiology. Fitness Technologies Press.

Kreider, R. B., Wilborn, C. D., Taylor, L., Campbell, B., Almada, A. L., Collins, R., ... \& Kerksick, C. M. (2010). ISSN exercise \& sport nutrition review: research \& recommendations. Journal of the International Society of Sports Nutrition, 7(1). https://doi.org/10.1186/1550-2783-7-7

Maughan, R. (2002). The athlete's diet: nutritional goals and dietary strategies. Proceedings of the nutrition Society, 61(1), 87-96. https://doi.org/10.1079/PNS2001132

Mcardle, W. D., Katch, F. I., \& Katch, V. L. (2010). Exercise physiology: nutrition, energy, and human performance. Lippincott Williams \& Wilkins.

Ostojic, S. M., \& Mazic, S. (2002). Effects of a carbohydrate-electrolyte drink on specific soccer tests and performance. Journal of sports science \& medicine, 1(2), 47.

Özdemir, G., \& Ersoy, G. (2009). Interaction of nutrition, health and performance in disabled athletes. Turkish Journal of Physical Medicine \& Rehabilitation, 55(3).

Pulur, A., \& Cicioğlu, İ. (2001). Nutritional knowledge and habits of female basketball players. Atatürk University Journal of Physical Education and Sports, 1(2), 44-49.

Richard, B., \& Kreider, V. D. (2004). "ISSN Exercise \& Sport Nutrition Review: Research \& Recommendations", Sports Nutrition Review Journal, 1(1), 1-44.

Rodriguez, N. R., Dimarco, N. M., \& Langley, S. (2009). Nutrition and athletic performance. Medicine and science in 
sports and exercise, 41(3), 709-731. https://doi.org/10.1249/MSS.0b013e31890eb86

Sağlam, F. (1993). Food habits of football players. Hacettepe Journal of Sport Sciences, 4(2), 27-34.

Şenel, Ö., Güler, D., Kaya, İ., Ersoy, A., \& Kürkçü, R. (2004). The level of knowledge on how to use ergogenic aids among elite class Turkish athletes in different individual branches. Ankara University Faculty of Sport Sciences Spormetre, 2(2), 41-47.

Süel, E., Şahin, İ., Karakaya, M. A., \& Savucu, Y. (2006). The nutritional knowledge and habits of basketball players in elit level. Firat University Medical Journal of Health, 20(4), 271-275.

Süel, E., Şahin, İ., Korkmaz, C., Süel, N., \& Dağlioğlu, O. (2009). Comparison of nutritional knowledge and habits of basketball players in young men's basketball group matches in Turkey and young sedentaries in the same age group. Journal of Human Sciences, 6(2), 239-251.

Turgut, M., Argun, B., Sarikaya, M., \& Çinar, V. (2015). The evaluation of the nutritional habits of athletes between the ages of 17-18 who perform the swimming sports. International Journal of Science Culture and Sport, 2(Special Issue 2), 242-254.

Ünsal, G. N., Özdemir, G., \& Ersoy, G. (2010). The assessment of the consumer awareness in nutritional support products usage. Firat University Medical Journal of Health Sciences, 24(2), 81-88.

Yarar, H., Gökdemir, K., Eroğlu, H., \& Özdemir, G. (2011). Evaluation of knowledge for diet and dietary habits of elite athletes. Selçuk University Journal of Physical Education and Sport Science, 13(3), 368-371.

Yildirim, Y., Miçooğullari, B. O., Yildirim, İ., \& Şahin F. N. (2005). Analyze of Nutrition Knowledge and Habits of Amateur Basketball Athletes (Hatay City Example). Atatürk University Journal of Physical Education and Sports, 7(4), 12-22.

\section{Copyrights}

Copyright for this article is retained by the author(s), with first publication rights granted to the journal.

This is an open-access article distributed under the terms and conditions of the Creative Commons Attribution license which permits unrestricted use, distribution, and reproduction in any medium, provided the original work is properly cited. 